\title{
FISH DIVERSITY UNDER HUMAN IMPACT: A CASE STUDY OF THE PRIPYAT RIVER BASIN IN UKRAINE
}

\author{
Grokhovska Yu. R., Konontsev S. V.
}

\section{INTRODUCTION}

The growing direct and indirect human impact on water bodies leads to a change in the hydrological and hydrochemical regime, violation of the living conditions of aquatic organisms and fish fauna in particular, and, in some cases, to complete degradation of aquatic ecosystems. The main threats to the ecosystems and fishes are habitat loss (including disruption of the bottom, removal of structure, water withdrawal, hydrologic alterations, eutrophication, and sediment deposition), introduced species, pollution, human population and consumption (the ultimate cause of everything), and overexploitation. These are the so-called HIPPO ${ }^{1}$, and Montgomery $(2003)^{2}$ added another H: history - that is, our inability to learn from past mistakes. In addition, global climate change is recognized as a growing threat to aquatic ecosystems and fishes (IPCC 2007) ${ }^{3 ; 4}$. Fish communities change quantitatively (decrease in abundance, patrticularly species with high commercial value) and qualitatively (decrease in biodiversity, particularly in endemic native species) ${ }^{5}$. The decrease in abundance and diversity of fishes is a reflection of humans' attitude towards biological resources; neglect to act according to basic rules for conservation of biotic productivity and diversity.

These negative trends are fully inherent in the fish fauna of the Rivne Oblast (region), which is one of the richest in freshwater bodies, in recent years provides only $1,1-2,1 \%$ of the total extraction of fish resources in Ukrainian inland waters (the fish have been growed in ponds by farming) (table 1).

\footnotetext{
${ }^{1}$ Helfman G. Fish conservation. A guide to understanding and restoring global fish biodiversity and fishery resources. Washington, DC : Island Press, 2007. 577 p.

2 Montgomery D. King of fish: The thousand year run of salmon. Boulder, CO : Westview Press, 2003. 304 p.

IPCC: Climate Change 2007 : Synthesis Report. Contribution of Working Groups I, II and III to the Fourth Assessment Report of the Intergovernmental Panel on Climate Change / Core Writing Team : R. Pachauri, A. Reisinger (eds.). IPCC, Geneva ; Switzerland, 2007. 104 p.

${ }_{4}^{4}$ Freyhof J., Brooks E. European Red List of Freshwater Fishes. Luxembourg : Publications Office of the European Union, 2011. DOI: 10.2779/85903.

5 Жукинский В., Харченко Т., Ляшенко А. Адвентивные виды и изменение ареалов аборигенных гидробионтов в поверхностных водных объектах Украины. Сообщение 2 : Лучеперые рыбы. Гидробиологический журнал. 2007. Т. 43. № 4. C. 3-24.
} 
Extraction of fish by fishery in inland water bodies in the Rivne Oblast (according to the State Statistics Service of Ukraine)

\begin{tabular}{|c|c|c|c|c|c|c|c|c|c|}
\hline Years & $\mathbf{2 0 1 0}$ & $\mathbf{2 0 1 1}$ & $\mathbf{2 0 1 2}$ & $\mathbf{2 0 1 3}$ & $\mathbf{2 0 1 4}$ & $\mathbf{2 0 1 5}$ & $\mathbf{2 0 1 6}$ & $\mathbf{2 0 1 7}$ & $\mathbf{2 0 1 8}$ \\
\hline $\begin{array}{c}\text { Volume of } \\
\text { extraction, } \\
\text { tons }\end{array}$ & 486 & 538 & 458 & 942 & 753 & 520 & 632 & 512 & 595,3 \\
\hline $\begin{array}{c}\text { in \% to } \\
\text { inland } \\
\text { freshwater } \\
\text { bodies in } \\
\text { Ukraine }\end{array}$ & 1,3 & 1,4 & 1,1 & 2,1 & 1,9 & 1,4 & 1,6 & 1,2 & 1,4 \\
\hline
\end{tabular}

The aim of the study was analysis of regional fish diversity (taxa, abundance, geography, and biology) and its geographical distribution under human impact.

\section{Methods}

The objects of the study were water bodies of Pripyat River basin (within the district of right bank tributaries in the middle part of the river) within the 16th European ecoregion by the Water Framework Directive $(2000)^{6}$ and Freshwater Ecoregion 425 by the Freshwater ecoregions of the world (FEOW, 2008) ${ }^{7}$.

Ichthyological studies were conducted on the basis of the ichthyology sector of The State Agency of Fisheries of Ukraine in the Rivne Oblast (in accordance with approved research programs in 2006-2011), as well as the Department of Aquatic Bioresources NUWEE (2009-2018). According to the obtained permits, the control catch of aquatic bioresources was carried out using a standard set of fixed nets. The studies covered the period from March to December. The 31 sites were located on six rivers, four lakes and four reservoirs in the Rivne Oblast. The collection and processing of material (table 2) were carried out according to generally accepted methods $8 ; 9 ; 10 ; 11$.

\footnotetext{
${ }^{6}$ Water Framework Directive (Directive 2000/60/EC of the European Parliament and of the Council of 23 October 2000 establishing a framework for Community action in the field of water policy). Official Journal of the European Communities. 2000. 72 p.

${ }^{7}$ Freshwater Ecoregions of the World: A New Map of Biogeographic Units for Freshwater Biodiversity Conservation / R. Abell Robin et al. BioScience. 2008. Vol. 58. Iss. 5. P. 403-414. DOI: 10.1641/B580507.

${ }^{8}$ Коблицкая А. Определитель молоди пресноводных рыб. Москва : Легкая и пищевая промышленность, 1981. 207 с.

${ }_{9}$ Маркевич О., Короткий І. Визначник прісноводних риб УРСР. Київ : Радянська школа, 1954. 209 с.

10 Методические рекомендации по контролю за состоянием рыбных запасов и оценке численности рыб на основе биостатистических данных. Москва : ВНИРО, 1987. 45 c.

11 Правдин И. Руководство по изучению рыб (преимущественно пресноводных). Москва : Пищ. пром-сть, 1966. 376 с.
} 
Table 2

The total number of ichthyological material in the main rivers

\begin{tabular}{|c|c|c|c|c|}
\hline River & Pripyat & Horyn & Styr & Sluch \\
\hline $\begin{array}{c}\text { The amount of processed ichthyological } \\
\text { material, specimens }\end{array}$ & 2184 & 2202 & 2628 & 1462 \\
\hline
\end{tabular}

The general list of species has been compiled by summarizing materials from scientific sources, fisheries data and own field studies, questionnaire survey of specialists and amateur fishers, processing of archival data and expositions of natural museums. Systematic, ecological, and biological characteristics of fish fauna are presented on the basis of literature sources ${ }^{12 ; 13 ; 14}$.

To assess species diversity, the Shannon diversity index $(H)$, the BergerParker dominance $(d)$ and the reciprocal indexes $(1 / d)$ were used ${ }^{15}$ :

$$
H=-\sum p_{i} \ln p_{i}
$$

where $p_{i}$ is the total number of species;

$$
d=N_{\max } / N,
$$

where $N_{\max }$ is the number of individuals of the most abundant species, and $N$ is the total number of specimens in the sample.

To assess correlation between surface water quality and fish species diversity, data from the Department of Ecology and Natural Resources of Rivne Regional State Administration, as well as the ichthyology sector of The State Agency of Fisheries of Ukraine in the Rivne Oblast (2006-2011), have been used. For comparison the results in those points that control both state agencies (one control point on the rivers Pripyat, Sluch, Stochod and Ikva, and two - on the rivers Goryn and Styr) have been used. Water quality was assessed by integral ecological index $\left(I_{e}\right)^{16}$.

\section{Fish diversity (taxa, abundance, geography, and biology)}

Current estimates indicate that the Rivne Oblast ichthyofauna consists of 43 fish species and one species of cyclostomes, which belong to 42 genera,

\footnotetext{
12 Берг Л. Рыбы пресных вод СССР и сопредельных стран. Москва ; Ленинград : Изд-во АН СССР, 1948-1949. Т. 1-3. 1370 с.

13 Фауна Украины: охранные категории : справочник / И. Парникоза и др. ; под ред. И. Загороднюка. Киев : Киевский эколого-культурный центр, 2005. 60 с.

${ }_{14}$ Кадастр іхтіофауни Рівненської області : монографія / Ю. Гроховська та ін. ; за ред. В. Мошинського, Ю. Гроховської. Рівне : ТзОВ «Дока-центр», 2012. 200 с.

${ }_{15}$ Berger W., Parker F. Diversity of Planktonic Foraminifera in Deep-Sea Sediments. Science. 1970. 168 (3937) : 1345-1347. DOI: 10.1126/science.168.3937.1345.

16 Методика екологічної оцінки якості поверхневих вод за відповідними категоріями / В. Романенко та ін. Київ : Символ-Т, 1998. 28 с.
} 
13 families, 8 orders and 2 classes. It represents $17,4 \%$ of total fish species diversity in Ukraine, and $0,16 \%$ in the world by Nelson (2006) ${ }^{17 ; 18}$ (table 3). Of these taxa, 8 genera and 9 species are allochthonous.

Table 3

Diversity of fishes in the Rivne Oblast / Ukraine / the world

\begin{tabular}{|l|c|c|c|}
\hline \multicolumn{1}{|c|}{ Orders } & Families & Genera & Species \\
\hline 1. Petromyzontiformes & $1 / 1 / 3$ & $1 / 1 / 10$ & $1 / 2 / 38$ \\
\hline 2. Anguilliformes & $1 / 2 / 15$ & $1 / 2 / 141$ & $1 / 2 / 791$ \\
\hline 3. Cypriniformes & $3 / 4 / 6$ & $29 / 36 / 321$ & $30 / 70 / 3268$ \\
\hline 4. Siluriformes & $2 / 2 / 35$ & $2 / 3 / 446$ & $2 / 3 / 2867$ \\
\hline 5. Esociformes & $1 / 2 / 2$ & $1 / 2 / 4$ & $1 / 2 / 10$ \\
\hline 6. Gadiformes & $1 / 2 / 9$ & $1 / 4 / 75$ & $1 / 4 / 555$ \\
\hline 7. Gasterosteiformes & $1 / 2 / 11$ & $2 / 5 / 71$ & $2 / 10 / 278$ \\
\hline 8. Perciformes & $3 / 25 / 160$ & $5 / 57 / 1539$ & $6 / 100 / 10033$ \\
\hline Total & \multicolumn{3}{|c|}{} \\
\hline In the Rivne Oblast & 13 & 42 & 44 \\
\hline In Ukraine* & 65 & 148 & 247 \\
\hline In the world ** & 515 & 4494 & 27977 \\
\hline
\end{tabular}

List of fishes in the Rivne Oblast

Phylum - Chordata.

Subphylum - Vertebrata.

Superclass - Cyclostomata.

1. Class: Hyperoartia.

1. Order: Petromyzontiformes (Berg, 1940).

1. Family: Petromyzontidae (A. Risso, 1827).

1. Genus: Eudontomyzon (Regan, 1911).

1. Species: Ukrainian brook lamprey - Eudontomyzon mariae (Berg, 1931).

2. Class: Actinopterygii (Klein, 1885).

1. Subclass: Neopterygii (Regan, 1923).

Infraclass - Teleostei (Muller, 1845).

2. Order: Anguilliformes (Berg, 1943).

2. Family: Anguillidae (Rafinesque, 1810).

2. Genus: Anguilla (Garsault, 1764).

2. European eel - Anguilla anguilla (Linnaeus, 1758).

3. Order: Cypriniformes (Goodrich, 1909).

3. Family: Cyprinidae (Fleming, 1822).

3. Genus: Leuciscus (Cuvier, 1816).

3. Common dace-Leuciscus leuciscus (Linnaeus, 1758). $601 \mathrm{p}$

${ }^{17}$ Nelson J. Fishes of the World. $4^{\text {th }}$ Edition. Hoboken : John Wiley \& Sons, 2006.

\footnotetext{
Мовчан Ю. Риби України : таксономія, номенклатура, зауваження. Збірник
} праць Зоологічного музею. 2008-2009. № 40. С. 47-78. 
4. Ide - Leuciscus idus (Linnaeus, 1758).

4. Genus: Squalius (Bonaparte, 1837).

5. Common chub - Squalius cephalus (Linnaeus, 1758).

6. Genus: Rutilus (Rafinesque, 1820).

6. Common roach - Rutilus rutilus (Linnaeus, 1758).

7. Genus: Scardinius (Bonaparte, 1837).

7. Common rudd - Scardinius erythrophthalmus (Linnaeus, 1758).

8. Genus: Chondrostoma (Agassiz, 1832).

8. Common sneep - Chondrostoma nasus (Linnaeus, 1758).

9. Genus: Alburnoides (Jeitteles, 1861).

9. Russian bystranka - Alburnoides rossicus (Berg, 1924).

10. Genus: Alburnus (Rafinesque, 1820).

10. Bleak - Alburnus alburnus (Linnaeus, 1758).

11. Genus: Leucaspius (Heckel \& Kner, 1858).

11. Sunbleak - Leucaspius delineatus (Heckel, 1843). 1889).

12. Genus: Eupallasella (Dybowski, 1916) (= Rhynchocypris Gunther,

12. Lake minnow - Eupallasella percnurus (Pallas, 1814).

13. Genus: Phoxinus (Rafinesque, 1820).

13. Common minnow - Phoxinus phoxinus (Linnaeus, 1758).

14. Genus: Vimba (Fitzinger, 1873).

14. Common vimba - Vimba vimba (Linnaeus, 1758).

15. Genus: Blicca (Heckel, 1843).

15. Silver bream - Blicca bjoerkna (Linnaeus, 1758).

16. Genus: Abramis (Cuvier, 1816).

16. Common bream - Abramis brama (Linnaeus, 1758).

17. Genus: Ballerus (Heckel, 1843).

17. European white-eye bream - Ballerus sapa (Pallas, 1814).

18. Genus: Aspius (Agassiz, 1832).

18. European asp - Aspius aspius (Linnaeus, 1758).

19. Genus: Hypophthalmichthys (Bleeker, 1859).

19. Silver carp - Hypophthalmichthys molitrix (Valenciennes, 1844).

20. Genus: Aristichthys (Oshima, 1919).

20. Bighead carp - Aristichthys nobilis (Richardson, 1845).

21. Genus: Pelecus (Agassiz, 1835).

21. Common sabrefish - Pelecus cultratus (Linnaeus, 1758).

22. Genus: Rhodeus (Agassiz, 1832).

22. European bitterling - Rhodeus amarus (Bloch, 1782).

23. Genus: Gobio (Cuvier, 1816).

23. Common gudgeon - Gobio gobio (Linnaeus, 1758).

24. Genus: Barbus (Cuvier, 1816).

24. Dnieper barbel - Barbus borysthenicus (Dybowski, 1862).

25. Genus: Ctenopharyngodon (Steindachner, 1866).

25. Grass carp - Ctenopharyngodon idella (Valenciennes, 1844). 
26. Genus: Cyprinus (Linnaeus, 1758).

26. Common carp - Cyprinus carpio (Linnaeus, 1758).

27. Genus: Carassius (Jarocki, 1822).

27. Crucian carp - Carassius carassius (Linnaeus, 1758).

28. Prussian carp - Carassius gibelio (Bloch, 1782).

28. Genus: Tinca (Cuvier, 1816).

29. Common tench - Tinca tinca (Linnaeus, 1758).

4. Family: Cobitidae (Swainson, 1839).

29. Genus: Cobitis (Linnaeus, 1758).

30. Spined loach - Cobitis taenia (Linnaeus, 1758).

30. Genus: Misgurnus (La Cepede, 1803).

31. Weather loach - Misgurnus fossilis (Linnaeus, 1758).

5. Family: Balitoridae (Swainson, 1839).

31. Genus: Barbatula (Linck, 1790).

32. Stone loach - Barbatula barbatula (Linnaeus, 1758).

4. Order: Siluriformes (Cuvier, 1817).

6. Family: Ictaluridae (Gill,1861).

32. Genus: Ameiurus (Rafinesque, 1820).

33. Brown bullhead - Ameiurus nebulosus (Le Sueur, 1819).

7. Family: Siluridae (Cuvier, 1816).

33. Genus: Silurus (Linnaeus, 1758).

34. European catfish - Silurus glanis (Linnaeus, 1758).

5. Order: Esociformes (Bleeker, 1858).

8. Family: Esocidae (Cuvier, 1816).

34. Genus: Esox (Linnaeus, 1758).

35. Nothern pike - Esox luceus (Linnaeus, 1758).

6. Order: Gadiformes (Goodrich, 1909).

9. Family: Lotidae (Bonaparte, 1837).

35. Genus: Lota (Oken, 1817).

36. River burbot - Lota lota (Linnaeus, 1758).

7. Order: Gasterosteiformes (Goodrich, 1909).

10. Family: Gasterosteidae (Bonaparte, 1831).

36. Genus: Pungitius (Coste, 1848). 1859).

37. Southern ninespined stickleback - Pungitius platygaster (Kessler,

37. Genus: Gasterosteus (Linnaeus, 1758).

38. European threespined stickleback - Gasterosteus aculeatus (Linnaeus, 1758).

8. Order: Perciformes (Bleeker, 1859).

11. Family: Percidae (Cuvier, 1816).

38. Genus: Sander Oken, 1817 (= Stizostedion Rafinesque, 1820).

39. Common zander - Sander lucioperca (Linnaeus, 1758).

39. Genus: Perca (Linnaeus, 1758).

40. European perch - Perca fluviatilis (Linnaeus, 1758). 
40. Genus: Gymnocephalus (Bloch, 1793).

41. Eurasian ruffe - Gymnocephalus cernua (Linnaeus, 1758).

42. Donets ruffe $-G$. acerinus (Gueldenstaedt, 1774).

12. Family: Odontobutidae (Hoese et Gill, 1993).

41. Genus: Perccottus (Dybowski, 1877).

43. Chinese (Amur) sleeper - Perccottus glenii (Dybowski, 1877).

13. Family: Gobiidae (Fleming, 1822).

42. Genus: Neogobius (Iljin, 1927).

44. Monkey goby - Neogobius fluviatilis (Pallas, 1814).

A quantitative analysis has shown that non-commercial and small-sized species dominated in catches: sunbleak (15-22\%), bleak (17\%), roach (8$13 \%)$, rudd $(6-8 \%)$, and perch $(4,5-7 \%)$. Common species were silver bream (4-6\%), bream $(2-5 \%)$, pike $(2-4,5 \%)$, crucian carp $(2-4,4 \%)$, tench (1-3\%), weather loach $(1,5-5 \%)$, ruff $(1,6-3 \%)$, Prussian carp $(0,4-2,4 \%)$, and bitterling $(0,5-2 \%)$. Common and crucian carp, ide, asp, catfish, monkey goby, amur sleeper (about 1\%) were rarely caught. The other 23 species hardly ever were in catches (less than $1 \%$ ).

There are rare species (by Red Data Book of Ukraine, 2009) ${ }^{19}$ : vulnerable (Leuciscus leuciscus, Carassius carassius, Alburnoides rossicus) and endangered (Eudontomyzon mariae, Alburnoides rossicus, Barbus borysthenicus, Lota lota, Gymnocephalus acerinus). The fraction of rare species is $18,2 \%$ of the total number of taxa, while the territories that have been created for ichthyofauna conservation are not sufficient: they cover only $1,8 \%$ of the network of the region's natural reserve fund. Therefore, the most pressing issue is granting the status of nature reserves to individual water bodies or their areas where rare species are inhabited.

A zoogeographic analysis has shown the representatives of nine faunal complexes (fig. 1). The Ponto-Caspian freshwater complex dominates quantitatively in the regional fish fauna. The complex includes Squalius cephalus, Scardinius erythrophthalmus, Chondrostoma nasus, Alburnoides rossicus, Alburnus alburnus, Leucaspius delineatus, Vimba vimba, Blicca bjoerkna, Abramis brama, Ballerus sapa, Aspius aspius, Pelecus cultratus, Barbus borysthenicus, Tinca tinca, Sander lucioperca, and Gymnocephalus acerinus (16 species).

19 Червона книга України. Тваринний світ / за ред. І. Акімова. Київ : Глобалконсалтинг, 2009. 623 с. 


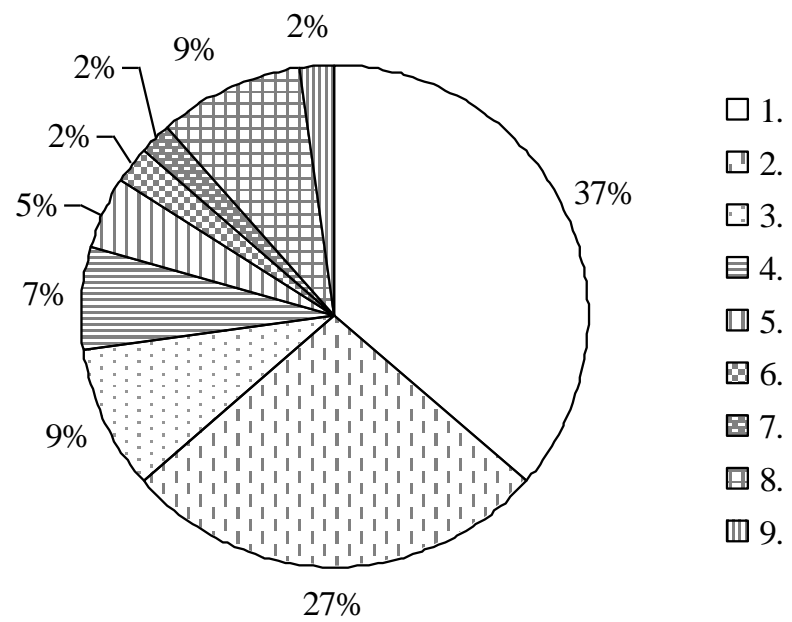

Fig. 1. The spectrum of fish faunal complexes: 1 - Ponto-Caspian freshwater, 2 - Boreal plain, 3 - Upper tertiary plain, 4 - Boreal foothill, 5 - Ponto-Caspian marine, 6 - Arctic freshwater, 7 - Boreal marine, 8 - Chinese plain, 9 - Nearctic

In the second place by number of species is Boreal plain complex: Anguilla anguilla, Leuciscus leuciscus, Idus idus, Rutilus rutilus, Eupallasella percnurus, Gobio gobio, Carassius carassius, C. gibelio, Cobitis taenia, Esox luceus, Perca fluviatilis, and Gymnocephalus cernuus (12). Upper tertiary plain complex is represented by Rhodeus amarus, Cyprinus carpio, Misgurnus fossilis, Silurus glanis (4); Boreal foothill complex - Eudontomyzon mariae, Phoxinus phoxinus, Barbatula barbatula (3); Ponto-Caspian marine complex - Pungitius platygaster, Neogobius fluviatilis (2); Arctic freshwater complex - Lota lota. Such geographical composition is common among fish faunas of the Dnieper, Volga, and Don rivers ${ }^{20 ; 21 ; 22}$.

Species of the Chinese plain complex (Hypophthalmichthys molitrix, Aristichthys nobilis, Ctenopharyngodon idella) introduced into local water bodies to provide economic benefits. For example, original purpose of introduction Ctenopharyngodon idella is vegetation control. Invasive Perccottus glenii belongs to the same complex. The group of invasive species also includes Pungitius platygaster (Boreal marine complex),

${ }^{20}$ Берг Л. Рыбы пресных вод СССР и сопредельных стран : в 2-х т. Москва ; Ленинград : Изд-во АН СССР, 1948-1949. Т. 1-3. 1370 с.

${ }^{21}$ Щербуха А. До створення кадастру іхтіофауни України. Жива Украӥна. 2004. № № 1-3. C. 10-11.

22 Щербуха А. Іхтіофауна України у ретроспективі та сучасні проблеми збереження іії різноманіття. Вісник зоологіï. 2004. № 38 (3). С. 3-18. 
Gasterosteus aculeatus (Ponto-Caspian marine complex), and Ameiurus nebulosus (Nearctic, originating from North America).

A major result of the combination of alien invasions and native species extinctions is biotic homogenization. The process is a worldwide phenomenon, in particular, species richness of fish in North America is growing due to invaders ${ }^{23}$. Among the nine alien species in the Rivne Oblast there are representatives of three categories due to the classification by Slynko, Tereshchenko $(2014)^{24}$ : A - species that are deliberately or accidentally introduced by humans, whose maternal range does not directly come into contact with the basin of a river ( 5 species). The Chinese carps are not biologically naturalized species, they are unable to reproduce and sustain a population without the support of humans ${ }^{25} ; \mathrm{R}$ - species that used to live in the basin and are now reintroduced by humans (Cyprinus carpio, Carassius gibelio); I - species settled independently in the basin from nearby historical areas (Gasterosteus aculeatus, Pungitius platygaster). These two species are euryphages, whose impact is significantly negative: they eat eggs and larvae of commercial fish and they are competitors in feed ${ }^{26}$.

Alien species Ameiurus nebulosus and Perccottus glenii are particularly dangerous to native fish species. They are invaders who naturalized, their number in the region is not very large now, but there is a danger of expansion and abundance increase. As it established ${ }^{27}$, that reliable preventive methods against large-scale geographical expansion of Perccottus glenii within Eurasia are absent.

Global warming induces shrinking of areals of cold-water Arctic and Boreal species; the reduction of their distribution in the region is enhanced by anthropogenic factors - the consequences of runoff regulation and wetland drainage, eutrophication and water pollution. The impact of alien species of fish that have entered the aquatic ecosystems as a result of deliberate and accidental human activities is increasing.

According to The Red Data Book (2009), the largest losses in the fish fauna of Ukraine have got rheophilic and migratory fishes due to hydraulic engineering construction. The fish fauna of the region is formed mainly by limnophilic species - 17; limno-rheophilic - 9; rheo-limnophilic - 6 . Rheophiles (lamprey, dace, chub, common sneep, bystranka, common

${ }^{23}$ Rahel F. Homogenization of fish faunas across the United States. Science. 2000. Vol. 288. P. 854-856.

${ }^{24}$ Слынько Ю., Терещенко В. Рыбы пресных вод Понто-Каспийского бассейна (разнообразие, фауногенез, динамика популяций, механизмы адаптаций). Москва : Полиграф-Плюс, 2014. 328 с.

${ }^{25}$ To be, or not to be, a non-native freshwater fish? / G. Copp et al. Journal of Applied Ichthyology. 2005. № 21. P. 242-262. DOI: 10.1111/j.1439-0426.2005.00690.

26 Сухойван П., Вятчанина Л. Рыбное население и его продуктивность. Беспозвоночные и рыбы Днепра и его водохранилищ. Киев : Наукова думка, 1989. C. $136-173$.

${ }^{27}$ Reshetnikov A., Ficetola G. Potential range of the invasive fish rotan (Perccottus glenii). Biological Invasions. 2011. № 13. P. 2967-2980. DOI: 10.1007/s10530-011-9982-1. 
minnow, gudgeon, barbel, weather loach, stone loach, and monkey goby) have been extremely rare in catches. Hydrotechnical construction which was aimed at creating water reserves and generating hydropower, but destroyed the migrate species in the Dnieper basin in the $20^{\text {th }}$ century, at this stage significantly reduces the distribution of rheophiles, which comprise 18-20\% of the species composition of fish communities and $27 \%$ of the total species wealth of fish fauna of the studied water bodies.

By feeding biology, the largest guild is benthophages (19 species): common minnow, vimba, bream, silver bream, gudgeon, barbel, grass and common carps, sneep, tench, spined loach, weather loach, stone loach, common ruffe, monkey goby, crucian carp. Freshwater non-parasitic lamprey (Eudontomyzon mariae) also belongs to this guild. Euryphagous species consume different foods (10): dace, chub, ide, roach, rudd, lake minnow, bream, bitterling, threespined and ninespined sticklebacks. Guild of predators consists of ichthyophages, ichthyo-benthophages, and euryphages: eel, asp, pike perch, pike, catfish, burbot, perch, brown bullhead, Amur sleeper and optional predator - sabrefish (10). Small forms of zooplankton are consumed by almost all fish species in the early ontogenesis, however, typical planktophages are bystranka, bleak, sunbleak, silver carp, and bighead carp (5).

Reproductive biology. By number of breeding opportunities there are two semelparous species (lampreys and eel), other species are iteroparous. Only one species belongs to group of winter spawners - river burbot (Lota lota), the rest species belong to spring and summer spawners.

Most species (51\%) are phytophils (Fig. 2): sunbleak, bream, loach, silver bream, rudd, common bream, tench, lake minnow, european perch, roache, sleeper, catfish, pikeperch, bleak, ide, spined loach, pike, crucian carp, prussian carp, common carp, threespined and ninespined sticklebacks.

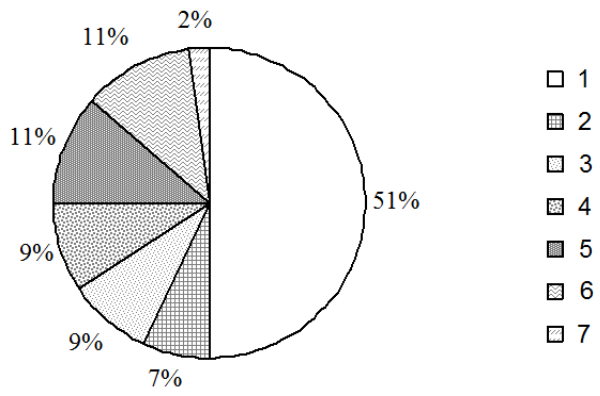

Fig. 2. The spectrum of reproductive guilds: 1 - phytophils, 2 - psammo-phytophils, 3 - psammophils, 4 - psammo-lithophils, 5 - lithophils, 6 - pelagophils, 7 - ostracophils 
Four species (9\%) belong to the psammophile guild: lamprey, dace, gudgeon, and burbot. Five species (11\%) are lithophils: common sneep, common minnow, bystranka, vimba, and barbel. The guild of psammolithophils includes four species (9\%): asp, chub, Don pope, and monkey goby. The guild of psammo-phytophils includes three species (7\%): brown bullhead, stone loach, and common ruffe. The guild of pelagophils consists of two native species - sabrefish and eel, and three species, which introduced by humans - silver carp, bighead carp, and grass carp. These species have not found conditions for natural spawning and their number is maintained due to artificial reproduction. Ostracophilic species in the region have been presented only by Rhodeus amarus, which lays eggs into the mantle cavity of molluscs. Sticklebacks are plant-nest builder (a nest usually is attached to rooted plants, and guarde it). The guild of nest spawners also includes brown bullhead, pikeperch, catfish, and monkey goby, which build a nest from available material.

Thus, the analysis of biology and ecology has showed a quantitative predominance of limnophilic species (39\%), by the nutrition - euryphagous species $(43 \%)$, and by the spawning substrate - phytophils (51\%). Lithophils and psammophils are not numerous in the region as a result of human activities (slowing the flow, ruining the watershed, pollution, etc.). Necessary conditions for their spawning disappear because river bottom becomes silted.

\section{Geographic distribution of fish diversity}

The highest species richness was recorded in the Pripyat River basin (40 species), however, a high level of diversity by the Shannon index $(3,13)$ and a low degree of dominance $(0,15)$ were in the Sluch river basin. The river has better water quality and more diverse biotopes (Table 4). The lowest level of fish diversity according to the Shannon index $(2,66)$ and a high degree of dominance $(0,22)$ are characteristic to the Styr river fish communities.

Table 4

Species richness of fish fauna $(\mathrm{N})$, diversity $(\mathrm{H})$ and dominance (d) catch patterns in the basins of the main rivers of the region

\begin{tabular}{|c|c|c|c|c|}
\hline \multirow{2}{*}{ Indexes } & \multicolumn{4}{|c|}{ River basins } \\
\cline { 2 - 5 } & Pripyat & Styr & Horyn & Sluch \\
\hline$N$ & 40 & 38 & 39 & 36 \\
\hline$H$ & 2,87 & 2,66 & 2,89 & 3,13 \\
\hline$d$ & 0,17 & 0,22 & 0,21 & 0,15 \\
\hline $1 / d$ & 5,9 & 4,5 & 4,8 & 6,7 \\
\hline
\end{tabular}

Species richness is the highest within the Volyn Polesia, and the lowest within the Volyn Upland. High numbers of rare species were discovered within the Zhytomyr Polesia (table 5). 
Species richness in geographic regions

\begin{tabular}{|c|c|c|c|c|c|c|c|c|c|}
\hline & \multirow{3}{*}{$\begin{array}{c}\text { Geographic regions } \\
\text { Number } \\
\text { of sites }\end{array}$} & \multicolumn{9}{|c|}{ Total } & \multicolumn{4}{|c|}{$\begin{array}{c}\text { Endangered species, } \\
\text { the Red Book (2009) }\end{array}$} \\
\cline { 3 - 10 } & & $\mathbf{m i n}$ & $\mathbf{m a x}$ & $\boldsymbol{N}$ & $\mathbf{\pm n}$ & $\mathbf{m i n}$ & $\mathbf{m a x}$ & $\boldsymbol{N}$ & $\mathbf{\pm n}$ \\
\hline Zhytomyr Polesia & 5 & 20 & 36 & 31,2 & 2,95 & 1 & 6 & 4,2 & 0,86 \\
\hline Volyn Polesia & 18 & 22 & 36 & 31,05 & 1,1 & 1 & 6 & 3,8 & 0,4 \\
\hline Volyn Upland & 8 & 22 & 33 & 28,13 & 1,7 & 0 & 5 & 3,0 & 0,75 \\
\hline
\end{tabular}

Therefore, the study illustrates the decrease in species richness as total as rare species. This is caused by a greater habitat modification within Volyn Upland by human activities. Most of the territory is defined as Converted lands (FEOW, 2008). The species richness decreases slightly in the direction from the northern to the southern part of the region, as well as from west to east (Fig. 3).
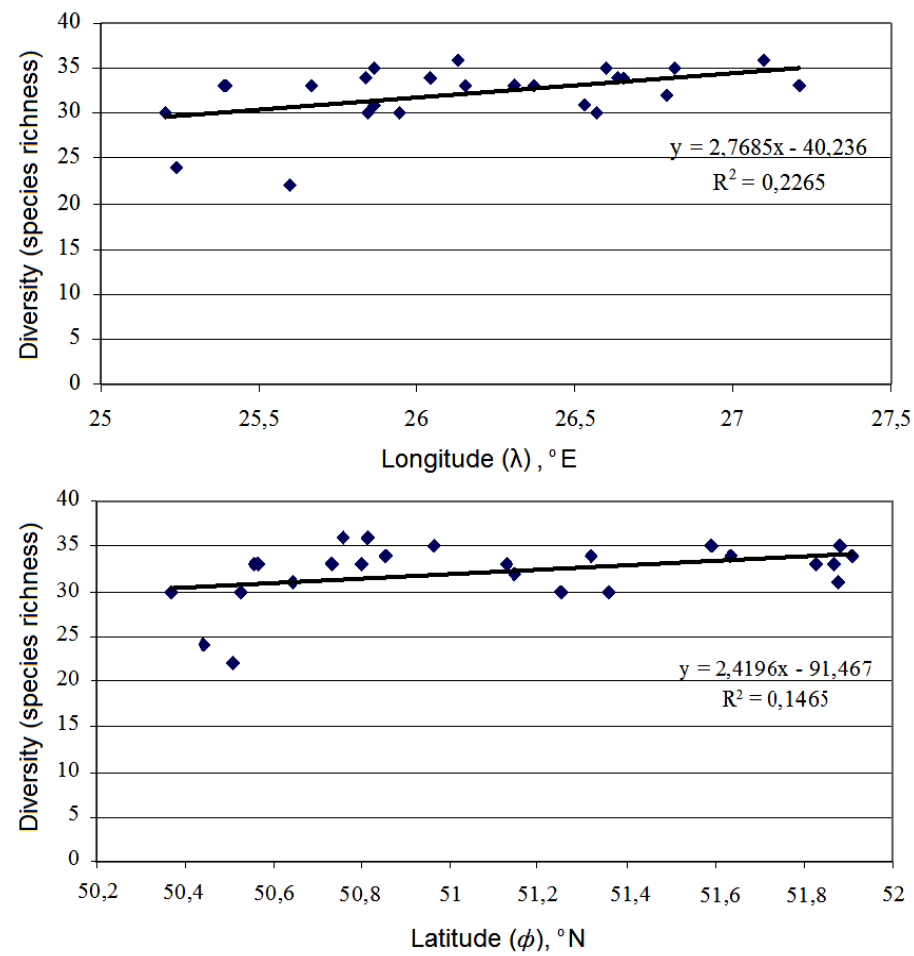

Fig. 3. Distribution patterns of fish fauna diversity in the Rivne Oblast in relation to geographic coordinates (in decimal) 
Water bodies have failed to meet the water quality criteria for freshwater fish habitat by indicators of chemical oxygen demand (excess of standards at $100 \%$ of all control points), biochemical oxygen demand $\mathrm{BOD}_{5}(96,4 \%$ of control points), and heavy metals concentrations $(\mathrm{Cu}-100 \%, \mathrm{Mn}-99 \%$, $\mathrm{Fe}-97 \%, \mathrm{Zn}-65 \%)$. The rivers are polluted by biogenic substances in significant quantities. In some sites below large settlements and industrial enterprises were noted enormous concentration of phosphorus (up to $2,7 \mathrm{mg} / \mathrm{L}$ ) and ammonia nitrogen (up to $11,55 \mathrm{mg} / \mathrm{L}$ ).

The ecological assessment of the water quality by the relevant categories showed that the water bodies belong to the II class by the average quality indicators (2-3 categories) and they are characterized as "clean" and "clean enough". According to the worst quality indicators, they belong to II-III classes, and they are characterized as "very clean" - "slightly polluted" - "moderately polluted".

Substantial connection between species richness and water quality of rivers in the region by integral ecological index values were found $\left(\mathrm{R}^{2}=0,76\right)$. Generally, the increase the $\mathrm{I}_{\mathrm{e}}$ index from 2,1 to 2,7 (29\%) by average and from 3,7 to $4,7(27 \%)$ by the worst values is associated with an increase in the species richness of the fish fauna from 30-33 to 35-36 species (6-20\%).

This suggests that river water pollution with biogenic macro- and microelements within certain limits contributes to an increase in the fish species diversity. Anthropogenic eutrophication increases biological productivity due to algae and vascular plants. This, in turn, contributes to the development of the animal population and, in particular, to the increase in the diversity of fish fauna. Indeed, a well-known regularity of species diversity is that a more productive environment is able to ensure the coexistence of a large number of species ${ }^{28}$. So, our empirical data coincide with the thesis that "maximum diversity can be expected with moderate stress, moderate, medium trophicity" ${ }^{29}$. But in combination with oxygen depletion by algae bloom can cause fish kill (as it has happened in the Ustia River, etc.).

Poaching is not the last factor in the deterioration of fish fauna. During 2019 in the Rivne Oblast 1027 cases of illegal fishing were detected, 538 nets have been confiscated from poachers, and fines were imposed in the amount of UAH 117,020, and fish weight $663 \mathrm{~kg}$ were seized. The largest numbers of offenses were detected in the Demydivka and Zarichne Raions. The destruction of valuable species, which occurs as a result of poaching, illustrates the socio-economic problems of society.

Latitudinal gradient of biodiversity is global pattern that correlates diversity declining with increasing latitude. In our studies a slightly different results - an increase in the fish fauna diversity in the northern direction. This

\footnotetext{
28 Бродский А. Введение в проблемы биоразнообразия : иллюстрированный справочник. Санкт-Петербург : Изд-во С.-Петербургского у-та, 2002. 144 с.

29 Ситник К. Біотичне різноманіття: сучасний стан, близькі та віддалені перспективи збереження, знищення та збагачення. Екологічні науки. 2013. С. 26-32.
} 
can be explained by the increasing diversity in the direction from tributaries to the main river - Pripyat, which flows in the north of the region. In addition, the southern part of the region underwent major anthropogenic transformations in the $20^{\text {th }}$ century and is now undergoing the influence of greater water pollution from point and diffuse sources. Our study results liable to another conclusion - the latitudinal pattern can be weak for freshwater systems compared to global marine and terrestrial systems ${ }^{30 ; 31}$.

Most threats to freshwater ecosystems (global climate change, pollution, eutrophication, species introductions, and overexploitation) will continue to affect fishes, contribute to the expansion of alien species by reducing local species and remain a challenge to human ability to comprehend and reduce the impacts on freshwater ecosystems and biodiversity.

\section{CONCLUSIONS}

Rivne Oblast (region) is one of the richest in natural water objects, but provides only $1,1-2,1 \%$ of the total production of aquatic living resources in inland waters of Ukraine. The regional ichthyofauna consists of 43 fish species and one species of cyclostomes. The species belong to 42 genera and 13 families. The fraction of rare species is $18,2 \%$ of the total number of taxa. The territories that were created for fish fauna conservation is insufficient it covers only $1,8 \%$ of the region's natural reserve fund network. The structure of catches was dominated by the non-commercial fish species. Of the nine invasive species, seven species are associated with human activities and three of them affect the native fish populations negatively.

The analysis has showed a quantitative predominance of limphophils species (39\%), by the nutrition - euryphagous species (43\%), and by the spawning substrate - phytophils $(51 \%)$. Hydrotechnical construction reduces the rheophilic species distribution; these were rare in catches, exclusively on the flowing sections of the Styr, Goryn and Sluch rivers. Necessary conditions for spawning of lithophils and psammophils disappear because rivers bottom becomes silted.

Species richness is the highest within the Volyn Polesia. High number of rare species was found within the Zhytomyr Polesia. The lowest species richness is caused by a greater habitat modification within Volyn Upland by human activities. Substantial connection between species richness and water quality by integral ecological index were found $\left(\mathrm{R}^{2}=0,76\right)$. Eutrophication (within 2-3 classes of water quality) contributes to growth of fish feed base and growth of species richness in some rivers (by 6-20\%), but, in combination with oxygen depletion by algae bloom, can caused fish kill.

30 Winemiller K., Leslie M. Fish assemblages across a complex, tropical freshwater/marine ecotone. Environmental Biology of Fishes. 1992. № 34 (1). P. 29-50.

${ }^{31}$ Hillebrand $\mathrm{H}$. On the generality of the latitudinal diversity gradient. American Naturalist. 2004. № 163 (2). P. 192-211. DOI: 10.1086/381004. 
Rare species disappearance is an illustration of extinction induced by humans. The most barbaric is illegal fishing, which very common in the region. In view of the trends in the reduction of total surface runoff resources under the global warming, the negative effects of these interconnected processes for fish diversity will increase in the future.

\section{SUMMARY}

The aim of the study was exploration regional fish diversity (taxa, abundance, geography, and biology) and its geographical distribution under human impact.

Rivne region is one of the richest in natural water objects, but provides only $1,1-2,1 \%$ of the total production of aquatic living resources in inland waters of Ukraine. 43 fish species and one species of cyclostomes may be found there. It represents $17,4 \%$ of their total quantity in Ukraine. Rheophilic fish species in catches were rare, exclusively on the flowing sections of the Styr, Goryn and Sluch rivers. The structure of catches was dominated by the number of non-commercial fish species. Of the nine invasive species, seven are related to economic activity and were deliberately or accidentally introduced or reintroduced by humans.

Species richness of ichthyofauna is the highest within the Volyn Polesia, and the lowest within the Volyn Upland. High numbers of rare species richness were found within the Zhytomyr Polesia. Substantial connection between species richness of fish fauna and water quality of rivers in Rivneregion by integral ecological index values were found $\left(R^{2}=0,76\right)$.

\section{REFERENCES}

1. Helfman G. Fish conservation. A guide to understanding and restoring global fish biodiversity and fishery resources. Washington, DC : Island Press, 2007. 577 p.

2. Montgomery D. King of fish: The thousand year run of salmon. Boulder, CO : Westview Press, 2003. 304 p.

3. IPCC: Climate Change 2007 : Synthesis Report. Contribution of Working Groups I, II and III to the Fourth Assessment Report of the Intergovernmental Panel on Climate Change / Core Writing Team : R. Pachauri, A. Reisinger (eds.). IPCC, Geneva ; Switzerland, 2007. 104 p.

4. Freyhof J., Brooks E. European Red List of Freshwater Fishes. Luxembourg : Publications Office of the European Union, 2011. DOI: $10.2779 / 85903$.

5. Жукинский В., Харченко Т., Ляшенко А. Адвентивные виды и изменение ареалов аборигенных гидробионтов в поверхностных водных объектах Украины. Сообщение 2 : Лучеперые рыбы. Гидробиологический журнал. 2007. Т. 43. № 4. С. 3-24.

6. Water Framework Directive (Directive 2000/60/EC of the European Parliament and of the Council of 23 October 2000 establishing a framework 
for Community action in the field of water policy). Official Journal of the European Communities. 2000. 72 p.

7. Freshwater Ecoregions of the World: A New Map of Biogeographic Units for Freshwater Biodiversity Conservatio / R. Robin Abell. BioScience. 2008. Vol. 58. Iss. 5. P. 403-414. DOI: 10.1641/B580507.

8. Коблицкая А. Ф. Определитель молоди пресноводных рыб. Москва : Легкая и пищевая промышленность, 1981. 207 с.

9. Маркевич О., Короткий І. Визначник прісноводних риб УРСР. Київ : Радянська школа, 1954. 209 с.

10. Методические рекомендации по контролю за состоянием рыбных запасов и оценке численности рыб на основе биостатистических данных. Москва : ВНИРО, 1987. 45 с.

11. Правдин И. Руководство по изучению рыб (преимущественно пресноводных). Москва : Пищ. пром-сть, 1966. 376 с.

12. Берг Л. Рыбы пресных вод СССР и сопредельных стран. Москва ; Ленинград : Изд-во АН СССР, 1948-1949. Т. 1-3. 1370 с.

13. Фауна Украины: охранные категории : справочник / И. Парникоза и др. ; под ред. И. Загороднюка. Киев : Киевский экологокультурный центр, 2005. 60 с.

14. Кадастр іхтіофауни Рівненської області : монографія Ю. Гроховська та ін. ; за ред. В. Мошинського, Ю. Гроховської. Рівне : ТзОВ «Дока-центр», 2012. 200 с.

15. Berger W., Parker F. Diversity of Planktonic Foraminifera in DeepSea Sediments. Science. 1970. 168 (3937) : 1345-1347. DOI: 10.1126/science.168.3937.1345.

16. Методика екологічної оцінки якості поверхневих вод за відповідними категоріями / В. Романенко та ін. Київ : Символ-Т, 1998. $28 \mathrm{c}$.

17. Nelson J. Fishes of the World. 4th Edition. Hoboken : John Wiley \& Sons, 2006. $601 \mathrm{p}$.

18. Мовчан Ю. Риби України : таксономія, номенклатура, зауваження. Збірник праць Зоологічного музею. 2008-2009. № 40. С. 47-78.

19. Червона книга України. Тваринний світ / за ред. І. Акімова. Київ : Глобалконсалтинг, 2009. 623 с.

20. Берг Л. Рыбы пресных вод СССР и сопредельных стран : в 2-х т. Москва ; Ленинград : Изд-во АН СССР, 1948-1949. Т. 1-3. 1370 с.

21. Щербуха А. До створення кадастру іхтіофауни України. Жива Украӥна. 2004. № № 1-3. С. 10-11.

22. Щербуха А. Іхтіофауна України у ретроспективі та сучасні проблеми збереження іiі різноманіття. Вісник зоології. 2004. № 38 (3). C. $3-18$.

23. Rahel F. Homogenization of fish faunas across the United States. Science. 2000. Vol. 288. P. 854-856. 
24. Слынько Ю., Терещенко В. Рыбы пресных вод Понто-Каспийского бассейна (разнообразие, фауногенез, динамика популяций, механизмы адаптаций). Москва : Полиграф-Плюс, 2014. 328 с.

25. To be, or not to be, a non-native freshwater fish? / G. Copp et al. Journal of Applied Ichthyology. 2005. № 21. P. 242-262. DOI: 10.1111/j.1439-0426.2005.00690.

26. Сухойван П., Вятчанина Л. Рыбное население и его продуктивность. Беспозвоночные и рыбы Днепра и его водохранилищ. Киев : Наукова думка, 1989. С. 136-173.

27. Reshetnikov A., Ficetola G. Potential range of the invasive fish rotan (Perccottus glenii). Biological Invasions. 2011. № 13. P. 2967-2980. DOI: 10.1007/s10530-011-9982-1.

28. Бродский А. Введение в проблемы биоразнообразия : иллюстрированный справочник. Санкт-Петербург : Изд-во С.-Петербургского у-та, 2002. $144 \mathrm{c}$.

29. Ситник К. Біотичне різноманіття: сучасний стан, близькі та віддалені перспективи збереження, знищення та збагачення. Екологічні науки. 2013. С. 26-32.

30. Winemiller K., Leslie M. Fish assemblages across a complex, tropical freshwater/marine ecotone. Environmental Biology of Fishes. 1992. № 34 (1). P. 29-50.

31. Hillebrand $\mathrm{H}$. On the generality of the latitudinal diversity gradient. American Naturalist. 2004. № 163 (2). P. 192-211. DOI: 10.1086/381004.

\section{Information about authors:} Grokhovska Yu. R.,

Doctor of Agricultural Sciences, Associate Professor at the Department of Water Bioresources National University of Water and Environmental Engineering 11, Soborna str., Rivne, 33028, Ukraine

Konontsev S. V., Doctor of Technical Sciences, Associate Professor at the Department of Water Bioresources National University of Water and Environmental Engineering 11, Soborna str., Rivne, 33028, Ukraine 